\title{
Erratum to: Ovariectomy alters energy metabolism in rat striatum: effect of supplementation with soy diet rich in isoflavones
}

\author{
Vanize Mackedanz $\cdot$ Cristiane B. Mattos • \\ Luciane R. Feksa • Clovis M. D. Wannmacher • \\ Angela T. S. Wyse
}

Published online: 28 May 2011

(C) Springer Science+Business Media, LLC 2011

Erratum to: Metabolic Brain Dis

DOI 10.1007/s11011-010-9216-8

The second paragraph in the "Experimental treatment" of the Material and Methods section should have contained the following information: "One week after surgery, animals were fed for 30 days with a standard diet with casein (control) or a special diet with soy isolated protein prepared according to Franzon et al. (2005) and Reeves et al. (1993). Food intake and body weight were examined weekly. Both diets were isocaloric."

The full reference for the above is as follows: Franzon F, Chiarani F, Mendes RH, Belló-Klein A, Wyse ATS (2005) Dietary soy prevents brain $\mathrm{Na}^{+}, \mathrm{K}^{+}$-ATPase reduction in streptozotocin diabetic rats. Diabetes Res Clin Pract 69:107-112.

Data included in Tables 1 and 2 has raised debate and should not be considered with the paper.

These corrections do not change the results and conclusions of the work.

The online version of the original article can be found at http://dx.doi. org/10.1007/s11011-010-9216-8.

V. Mackedanz $\cdot$ C. B. Mattos $\cdot$ A. T. S. Wyse

Laboratório de Neuroproteção e Doenças Metabólicas, Departamento de Bioquímica, Instituto de Ciências Básicas da Saúde, Universidade

Federal do Rio Grande do Sul, Porto Alegre, RS, Brazil

L. R. Feksa

Grupo de pesquisa em Bioanálises, Instituto de Ciências da Saúde,

Centro Universitário Feevale, Novo Hamburgo, RS, Brazil

C. M. D. Wannmacher $\cdot$ A. T. S. Wyse $(\square)$

Departamento de Bioquímica, ICBS,

Universidade Federal do Rio Grande do Sul, Rua Ramiro

Barcelos, 2600-Anexo, CEP 90035-003, Porto Alegre, RS, Brazil

e-mail: wyse@ufrgs.br 